JOURNAL Of CONTEMPORARY INDONESIAN ART

Jurusan Seni Murni FSR ISI Yogyakarta

ISSN: $2442-3394$

E-ISSN: 2442-3637

\title{
FIGUR MONSTER SEBAGAI METAFORA KEJAHATAN SEKSUAL TERSTRUKTUR DALAM VISUALISASI SENI GRAFIS
}

\author{
Oleh: Prasojo Yulistianto \\ Institusi: Pascasarjana Institut Seni Indonesia Yogyakarta \\ E-mail: prasojoyulis@yahoo.co.id
}

\begin{abstract}
ABSTRAK
Kejahatan seksual terhadap wanita sering terjadi di dunia kerja, dalam bentuk pelecehan seksual. Tindakan ini dapat terjadi di perusahaan kecil maupun besar, dan ironisnya dapat pula terjadi di lembaga pendidikan yaitu sekolah. Pada dunia kerja pelecehan sering terjadi antara atasan dan bawahan, sedangkan pada lembaga pendidikan antara pengajar dan murid, antara yang memiliki kuasa/kebijakan dan penerimanya. Hal ini adalah kenyataan pahit yang memang terjadi dan masih berulang. Tingkat pendidikan dan status sosial seseorang terkadang tidak menjamin dirinya memiliki nilai-nilai moral yang baik dan stabil, karena nilai moral manusia bersifat fluktuatif, terkadang naik dan turun. Penyebabnya adalah anggapan bahwa wanita dipandang hanya sebagai objek seks saja, hal ini menghilangkan sisi kemanusiaan pelakunya dan kurangnya pelatihan pada pegawai, atau edukasi pada murid bagaimana cara untuk mencegah tindakan ini menimpa mereka serta penyelesaiannya. Pelecehan seksual mengakibatkan kerugian baik secara fisik maupun mental pada korbannya. Penulis ingin mengungkapkan gagasan kritisnya mengenai fenomena ini lewat karya seni grafis, menghadirkan figur monster sebagai wujud metaforik.
\end{abstract}

Kata Kunci: Kejahatan Seksual Dunia Kerja, Media Seni Grafis, Monster Birahi

\begin{abstract}
Sexual crimes against women often occur in the professional world, in the form of sexual harassment. This action can occur in small and large companies, and ironically can also occur in educational institutions, namely schools. In the professional world, harassment often occurs between superiors and subordinates, while in educational institutions between teachers and students, between those who have the power/ policy and the recipient. It is a bitter reality that does occur and is still recurring. The level of education and social status of a person sometimes does not guarantee that they have good and stable moral values because human moral values are fluctuating, sometimes up and sometimes down. The reason is the assumption that women are seen only as sex objects, this eliminates the human side of the perpetrators and the lack of training for employees or educating students on how to prevent these actions from happening to them and their solutions. Sexual harassment inflicts physical and mental harm on the victim. The author wants to express his critical ideas about this phenomenon through graphic artworks, presenting a monster figure as a metaphoric form.
\end{abstract}

Key Words: Criticism of Sexual Crimes, Lust Monsters, Printmaking Media 


\section{A. Pendahuluan}

Dalam dunia kerja sering kali karyawati dituntut untuk memuaskan keinginan pimpinan atau orang yang memiliki jabatan tinggi di suatu perusahaan, adanya suatu tuntutan lain bagi para karyawati untuk berdandan dengan menarik, mengenakan pakaian yang seksi, hingga seragam kerja yang sudah didesain khusus untuk para karyawati. Padahal yang lebih dibutuhkan adalah kinerja, keterampilan dan pengetahuan yang dimiliki oleh karyawati tersebut. Hal ini menunjukkan adanya sistem yang ditentukan oleh pihak yang memiliki jabatan untuk membuat karyawatinya tidak hanya berfungsi sebagai pekerja namun juga sebagai penghibur dan pemuas nafsu para pimpinan yang bermain. Tidak jarang terjadi di perusahaan atau pekerjaan lain, agar wanita dapat memiliki jenjang karir yang bagus harus mengikuti kemauan pimpinan diluar kewajiban pekerjaan, seperti harus bersedia diajak berkencan, bahkan sampai bersedia dijadikan wanita simpanan, dsb. Contoh lainnya adalah pramugari maskapai penerbangan, yang lolos seleksi adalah yang menarik secara fisik dan kemudian harus mengenakan seragam yang sudah didesain untuk menunjukkan bentuk lekuk tubuh dan rok yang hampir menunjukkan bagian paha. Kebutuhan ekonomi membuat wanita mau tidak mau menerima segala ketentuan tersebut. Adanya suatu represi yang diterima wanita dalam dunia kerja, yang tidak seharusnya ada, seolah wanita hanya dipandang sebagai makhluk visual pemuas mata. di mana harkat dan martabatnya dipandang lebih rendah dari laki-laki yang notabenenya sering menjadi pemimpin. Penulis ingin mengkritisi hal tersebut lewat karya seni ciptaannya. Pada era modern saat ini, ada berbagai bentuk kejahatan seksual terhadap wanita, antara lain pemerkosaan, begal payudara, tindakan eksibisionis, menggesek-gesekkan alat kelamin pada bagian tubuh korban di angkutan umum, pelecehan verbal, dan masih banyak lagi. Menurut Mansour Fakih, kejahatan seksual pemerkosaan terhadap wanita terjadi karena seseorang melakukan pemaksaan untuk memperoleh pelayanan seksual tanpa kerelaan yang bersangkutan (Fakih, 1996, p. 17). Dalam penciptaan karya ini, penulis menggunakan sumber berita dari media massa online mengenai kasus kejahatan seksual.

Media kabar di Malaysia, memberitakan seorang Tenaga Kerja Wanita asal Indonesia yang melaporkan majikannya atas tindak pemerkosaan terhadap dirinya, pelaku adalah Paul Yong, seorang anggota dewan eksekutif Perak, sedangkan pihak KBRI Kuala Lumpur telah menemui korban secara langsung dan melihat korban dalam kondisi trauma psikis, akhirnya dilakukan penyelidikan pada terduga menggunakan Pasal 375 KUHP Malaysia, ketika kasus ini sedang berjalan muncul pula kabar bahwa Paul Yong juga pernah melecehkan sekretaris pribadinya, akhirnya baik pihak KBRI, Partai pengusung, dan pelaku pun menyerahkan kasus ini sepenuhnya pada pihak yang berwenang, meskipun kepada media, pelaku tidak mengakui perbuatannya (Rizki, Akbar Hasan: Mei 2020), Liputan6.com, Kuala Lumpur).

\section{B. Rumusan Penciptaan}

Berdasarkan latar belakang yang telah disampaikan, dapat dirumuskan beberapa pertanyaan sebagai berikut:

1. Bagaimana figur monster sebagai metafora kejahatan seksual terstruktur menjadi gagasan dalam penciptaan karya seni rupa?

2. Idiom bentuk dan gaya seperti apa yang akan digunakan dalam memvisualisasikan kejadian dan mengungkapkan gagasan dalam karya seni rupa?

3. Teknik dan medium seni grafis apakah yang sesuai untuk mengungkapkan gagasan tersebut?

\section{Tujuan}

Adapun tujuan dari penciptaan karya ini adalah :

1. Sebagai media ekspresi dari refleksi penulis terhadap kasus kejahatan seksual terstruktur, memunculkan segala dampak 
yang dialami oleh wanita korban kejahatan seksual dengan pemilihan objek visual yang bersifat metafora, dengan pemaknaan khusus dari penulis.

2. Sebagai media kritik dan penyadaran bagi masyarakat untuk selalu menghargai harkat dan martabat wanita sebagai sesama manusia yang memiliki derajat yang sama.

\section{Landasan teori}

Berdasarkan latar belakang kasus kejahatan yang menarik perhatian sekaligus keprihatinan, dapat dikatakan kejahatan seksual terjadi karena adanya suatu pandangan atau persepsi dalam masyarakat. Pandangan atau persepsi yang ada sebagai hasil dari suatu sistem yang mengendalikan dan mendominasi, di mana antara persepsi masyarakat dan sistem tersebut saling bersinergi dan mempengaruhi. Dua hal tersebut adalah Budaya Patriarki dan Sistem Kapitalisme, oleh karena itu penulis menggunakan teori Hegemoni Marxisme, Teori Feminisme, dan Teori Kritis Sosial, Teori Hegemoni Marxisme.

1. Sejarah peradaban manusia yang dikontrol oleh produksi pengetahuan Barat.

2. Kekuasaan mendominasi yang dilakukan oleh satu kelompok sosial atas kelompok sosial lainnya.

3. Seni adalah tidak bebas nilai, tetapi harus memiliki keterlibatan terhadap upaya perubahan sosial yang lebih adil.

Sejarah peradaban manusia sudah lama sekali dikontrol oleh produksi pengetahuan Barat, misalnya saja dalam dunia pendidikan, siswa diberikan seragam sebagai penanda bahwa mereka anakanak yang terdidik dan siapapun berhak menyalahkan si anak apabila bertindak tidak sesuai aturan yang "berlaku". Seragam adalah produksi budaya barat yang saat ini dipakai oleh hampir seluruh warga dunia, termasuk dalam dunia kerja. Seragam formal selalu dikategorikan sebagai kemeja berkerah apapun motifnya, desain baju berkerah seperti ini juga merupakan produksi budaya barat. Sehingga satu dunia memiliki model kemeja berkerah yang sama untuk acara formal yang dipakai oleh pekerja yang biasanya bukan pimpinan, sedangkan pimpinan ditambahkan jas. Dari hal tersebut sudah menunjukkan perbedaan kelas sosial dalam masyarakat.

Formalitas yang merupakan budaya barat dengan klaim membuat manusia menjadi beradab juga terjadi di Indonesia, seperti seragam pramugari merupakan seragam formal maskapai penerbangan yang mengikuti desain Barat sebagai tempat awal ditemukannya pesawat terbang. Ketika tubuh dijadikan komoditas di dalam masyarakat Patriarki, segala potensi tubuh dieksploitasi sebagai cara menarik perhatian, khususnya elemenelemen "sensualitas". Inilah yang disebut "teknokrasi sensualitas" di mana nilai tanda sensualitas digunakan sebagai daya tarik sebuah komoditas yang sebetulnya tidak menarik. "Teknokrasi Sensualitas" adalah mekanisme mengendalikan pikiran konsumer melalui penampilan sensualitas. Disini bekerja prinsip voyeurism, yaitu kepuasan khayalan yang diperoleh melalui citra tubuh di dalam berbagai sistem komoditas (Raditya, 2014, p. xxv). Ketika wanita sebagai objek tatapan laki-laki, terjadinya visualisasi dan materialisasi wanita sebagai benda atau alat untuk menghibur pelanggan dan meningkatkan keuntungan perusahaan.

Kasus kejahatan seksual di dunia kerja adalah bentuk penindasan dan dominasi kaum borjuis terhadap kaum menengah, di mana kaum borjuis dapat mengatur hidup si karyawan. Pada dasarnya wanita pekerja tidak ingin harga dirinya dipermainkan oleh atasannya, namun faktor ekonomi dan gaya hidup menuntut mereka untuk menerima segala permainan atasan/pemimpin perusahaan. Hal ini juga merupakan produk industri kapitalis di mana masyarakat didoktrin bahwa memiliki benda-benda tersier yang berlabel akan turut menentukan tingginya status mereka di masyarakat.

Hegemoni satu kelompok atas kelompok-kelompok lainnya dalam pengertian Gramscian bukanlah sesuatu yang dipaksakan. Hegemoni 
itu harus diraih melalui upaya-upaya politis, kultural dan intelektual guna menciptakan pandangan dunia bersama bagi seluruh masyarakat. Teori politik Gramsci menjelaskan bagaimana ide-ide atau ideologi menjadi sebuah instrumen dominasi yang memberikan pada kelompok penguasa legitimasi untuk berkuasa. Dalam Teori Feminisme, menganggap sejarah pengetahuan sosial dan teoriteori ilmu sosial dirumuskan dengan dominasi dari perspektif pria. Sehingga dunia sosial yang terbentuk memposisikan wanita secara marjinal. Kenyataan historis ini menciptakan jurang ketimpangan antara wanita dan pria di mana yang satu didominasi dan yang lain mendominasi. Kejahatan seksual disebabkan oleh budaya Patriarki, budaya patriarki adalah sebuah budaya yang menempatkan pria sebagai warga kelas satu, dominan, superior dan lebih tinggi dari wanita, sementara wanita menjadi warga kelas dua, inferior dan lebih rendah. Dengan kenyataan tersebut maka akan menimbulkan adanya relasi yang tidak seimbang yakni anggapan masyarakat bahwa pria memiliki kedudukan yang lebih tinggi daripada wanita, sehingga pria merasa lebih berkuasa atas wanita (Annisa, 2007 , p. 3). Dalam kondisi seperti ini, pria berpeluang melakukan kejahatan seksual.

Teori feminisme muncul untuk melawan ketidakadilan terhadap kaum wanita, tidak hanya melawan penindasan yang dilakukan oleh budaya patriarki, namun juga struktur lain seperti kapitalisme. Dalam masyarakat kapitalistik, wanita direduksi menjadi tubuh dan diposisikan sebagai objek alih-alih subjek seksual. Kapitalisme menjual tubuh wanita atas nama profit, seperti pada iklan-iklan sabun di media yang menggunakan tubuh wanita untuk menarik pelanggan (Teori Feminisme, Sosiologis.com). Terjadinya eksploitasi tubuh wanita sekaligus pendoktrinan kepada masyarakat bahwa tubuh ideal adalah yang ditampilkan dalam iklan tersebut. Dari hal tersebut dapat menghasilkan keuntungan lain bagi kapitalis, dengan masyarakat yang sudah terbentuk persepsinya tentang apa itu standar cantik dan ideal bagi wanita, maka muncul beragam alat dan konsumsi yang membuat masyarakat mengejar standar cantik tersebut. Masih terjadi kekerasan simbolik terhadap wanita dalam masyarakat patriarki, ketika wanita dijadikan sebagai objek visual yang pasif, bukan subjek aktif yang memandang dan berpikir.

Teori kritik sosial muncul di Jerman sebagai respons ketidakpuasan terhadap bagaimana upaya menjelaskan realitas sosial dari berbagai perspektif yang berkembang pada saat itu. Institusi yang meluncurkan gagasan-gagasan teori kritik sosial adalah Frankfurter Schule atau di Indonesia lebih populer disebut sebagai Frankfurt School yang kemudian diterjemahkan dengan kata Mazhab Frankfurt (Wahyono, S. Bayu, 2020). Teori kritis lahir dari tradisi pemikiran Marxian. Dengan kata lain, seorang tokoh intelektual Karl Marx menjadi salah satu sosok inspiratif teori ini. Fondasi teori kritis juga tidak lepas dari pengembangan teori Marx yang dilakukan oleh intelektual Marxist seperti Gyorgy Lukacs dan Antonio Gramsci. Keduanya menginspirasi secara teoritis dan praksis pemikiran tokoh intelektual dari Universitas Frankfurt, Jerman seperti Max Horkheimer, Theodor Adorno, Herbert Marcuse, Erich Fromm, Walter Benjamin dan Juergen Habermas. Mereka itulah yang mengembangkan konsep dan definisi dari teori kritis.

Teori kritis bertujuan untuk menggali "kebenaran" yang beroperasi di bawah permukaankehidupan sosial, sepertiadanya praktik dominasi kekuasaan kapitalisme secara kultural dan ideologis. Dilihat dari pandangan Adorno, Televisi menciptakan budaya massa, karena Televisi adalah alat telekomunikasi satu arah kepada masyarakat, masyarakat tidak lagi sebagai subjek aktif, namun pasif. Masyarakat setiap detiknya disuguhkan kebutuhankebutuhan palsu yang menyebabkan meningkatnya konsumerisme. Sistem kapitalis turut mengatur selera masyarakat tersebut. Kapitalisme juga mampu bertahan dan menjamah semua masyarakat berbasis produksi tanda (nilai simbolis). Produk 
yang dijual di pasaran bukan karena adanya kebutuhan masyarakat, melainkan rekayasa hasrat dan pikiran tentang adanya kebutuhan palsu.

Kebutuhan dasar manusia telah dibelokkan menjadi kebutuhan tandatanda. Dengan mengatasnamakan ikatan moral dan sosial, produk yang diiklankan dianggap sebagai bagian dari kebanggaan sekaligus kehormatan pemakainya, akhirnya mereka merasa menemukan identitas aslinya dalam praktik konsumtif. Padahal identitas ini hanyalah ilusi semata karena sengaja dibuat oleh kapitalisme untuk memenuhi kebutuhan hasrat manusia yang orientasinya mengejar kepuasan, kenikmatan, sensasi dan superioritas (Raditya, 2014, pp. 69-70). Dengan demikian tubuh manusia tidak lebih dari citra yang diciptakan melalui dunia maya. Nalar manusia telah digantikan dengan nalar konsumsi tiada henti (Ritzer \& Goodman, 2004, p. 140).

Kembali pada kasus pekerja wanita, contohnya pramugari di mana profesi mereka juga membentuk pencitraan di kalangan masyarakat, seperti gemar membeli barang-barang bermerk mahal untuk mempertahankan citra eksklusifnya. Hal tersebut menyebabkan wanita tetap menjalani profesinya sebagai pramugari atau karyawati walaupun di perusahaannya ada hal-hal yang menindas mereka. Lyotard dalam buku karangan Ardhie Raditya (2014, pp. 200-201) menjelaskan bahwa tubuh wanita dieksploitasi, nilai dirinya sebagai tanda (sign) terletak pada kemampuannya menghasilkan makna (meaning), konsep atau tema tertentu: sensualitas, kegairahan, kemolekan, keseksian, kecantikan dan keindahan. Semua potensi inilah oleh para kapitalis dijadikan mesin pencetak "uang" dan mengakumulasi modal.

Dalam budaya kapitalisme, tubuh wanita tidak saja dieksplorasi nilai gunanya (use value) semisal pekerja seksual, ataupun nilai tukarnya (exchange value) semisal peragawati, melainkan juga nilai tanda (sign value) dan hasratnya seperti pada VCD film erotis, dll. Eksplorasi tubuh tersebut berlangsung mengikuti model-model pembiakan secara cepat ataupun pelipatgandaan secara kilat, baik dalam sisi taktik, bentuk varian, teknik maupun medianya. Kapitalis menganggap bahwa tanda-tanda tubuh wanita mampu membangkitkan libido yang bisa diperjualbelikan. Sistem ekonomi libido adalah sebuah sistem ekonomi yang menjadikan segala bentuk potensi energi libido sebagai komoditi dalam rangka mendapatkan profit. Bagi intelektual Marxis memang selalu mendengungkan adanya perubahan dan tidak ada yang natural di dunia sosial, semuanya adalah konstruksi sosial, karena itu bisa diubah. Hanya saja memang kemudian hal yang terjadi adalah kemapanan itu dinaturalisasikan demi kemapanan struktur yang tidak adil dan menguntungkan kaum mapan juga. Seni tidaklah bebas nilai, tetapi harus memiliki keterlibatan terhadap upaya perubahan sosial yang lebih adil.

Dalam konsep penciptaan yang ingin dihadirkan oleh penulis, karya seni dapat digunakan sebagai media kritik terhadap fenomena dan realitas sosial yang terjadi di masa seniman itu hidup. Penulis ingin mengkritisi kasus kejahatan seksual di dunia kerja yang dialami oleh wanita lewat karya seninya dengan mengkritisi sistem yang sudah terkonstruksi dan mapan, serta yang terjadi pada lembaga pendidikan. Dengan daya gugahnya, karya seni dapat menarik empati dari para audiens dan bisa digunakan sebagai media penyadaran masyarakat. Dengan sikap kritisnya, seniman dapat berpihak pada rakyat kecil yang tertindas.

\section{A. Metode}

Dalam proses penciptaan karya seni, menurut Soedarso S.P. (2006, p. 127) terdapat banyak masalah yang timbul selama prosesnya, dari segi konsep dan tema maupun teknik eksekusi karyanya, namun pada dasarnya seni bisa berbentuk konsep, aksi eksekusi dari konsep tersebut, atau hasil dari padanya. Penggunaan simbol-simbol dalam seni rupa tidak secara langsung merepresentasikan bentuknya sendiri, bisa saja merepresentasikan 
sesuatu yang lain. Sebuah lukisan pemandangan bisa saja merupakan simbol dari kesegaran, sesuatu yang alami, atau kebesaran Tuhan.

$$
\text { Menurut Marianto (2015), }
$$

kemampuan untuk membuat ungkapanungkapan metaforik adalah kekuatan pikiran dan imajinasi manusia dalam menghadirkan gagasan baru, kreasi atau yang menawarkan kebaruan. Caranya dengan mengaitkan satu objek dengan objek lain atau menghubungkan satu objek dengan gejala sehingga dari penggabungan bias asosiatif itu muncul imaji dengan konsep yang unik. Seni, seperti halnya bahasa, adalah hasil penggabungan ungkapan pikiran dan visualisasi atas lingkungan fisik, realita budaya, dan permasalahan aktual yang melingkupi dan mempengaruhi si kreator. Metafora adalah pengungkapan suatu hal dengan meminjam dari hal yang lain; untuk memahaminya tidak cukup dari maknanya saja. Pada dasarnya semua kata dan nama adalah buatan manusia sendiri dalam membedakan berbagai hal, namun metafora dapat menata ulang persepsi manusia berdasarkan apa yang diungkapkannya. Metafora tidak bersifat konstatif, melainkan performatif; ia menuntut kita melakukan sesuatu. Melakukan sesuatu dengan kata, yaitu untuk mengubah cara kita berada dan melihat realitas, menghadirkan kenyataan baru dengan membuat manusia berpikir ke arah tertentu (Bambang, 1996, p. 109).

Dalam penciptaan karya seni ini, penulis menggunakan metafora dalam mengungkapkan gagasan pada karya seninya, pelaku kejahatan seksual dimetaforakan/dihadirkan sebagai monster, kata monster sendiri memiliki konotasi "negatif" dan menggiring audiens ke beberapa nilai semantiknya. Metafora monster terinspirasi dari bentuk Yokai (siluman Jepang) untuk figur antagonis, karena berdasarkan legendanya Yokai senang mengganggu dan merugikan manusia. Yokai tidak muncul secara spontan, tetapi merupakan bentuk yang direfleksikan dalam sebuah cermin dari jiwa yang mendalam. Oleh karenanya, mereka menunjukan semua perbuatan buruk yang dapat dilakukan oleh manusia. Mereka adalah sisi gelap dari sifat manusia, perwujudan imajinasi yang terburuk; Yokai yang selamanya tersembunyi dalam lubuk hati kita yang terdalam, selalu mencari kesempatan untuk muncul ke permukaan. Sebagai ahli berubah wujud yang hebat, mereka dapat mengubah bentuk mereka menjadi apa saja yang mereka mau, kapan saja (Ross, 2007, pp. 157-158).

Seni Grafis adalah seni cetak dua dimensional, disebut demikian karena dalam metodenya menggunakan prinsip mencetak klise/matriks (acuan cetak) yang sebelumnya sudah disiapkan sedemikian rupa (Tanama, 2020, p. 38), dicetak pada medium bidang datar seperti kertas, kanvas, dan sejenisnya. Di Indonesia sendiri, awal usia seni grafis dimulai dengan cetakan gambar panorama antropologi pedesaan (di Yogyakarta) pada majalah kebudayaan terbitan tahun 1950an. Seni grafis juga dimanfaatkan sebagai alat sebar gagasan ke media massa yang turut membakar semangat nasionalisme di awal kemerdekaan, serta sarat akan nilai-nilai kerakyatan. Penulis memilih seni grafis karena identik dengan tema sosial dan humanisme. Selain itu, dari sisi teknis, penulis lebih dapat membuat perencanaan tebal tipisnya garis dan volume kebendaan supaya lebih matang sebelum dicetak pada media.

Teknik handcoloring dipilih karena mempermudah dalam pembuatan beragam warna, mengakomodasi penyaluran spontanitas dalam menentukan warna dan memudahkan eksekusinya pada media. Aspek warna pada karya dapat memiliki makna tertentu sesuai maksud pencipta dan bisa hanya sebatas pembeda/penerang objek visual.

\section{B. Pembahasan}

Berdasarkan dampak yang muncul dari kejahatan seksual terhadap wanita, pada karya ini penulis mendapatkan ide dari kejahatan seksual yang menimpa wanita pekerja. Banyak penipuan-penipuan berkedok penyaluran tenaga kerja wanita 
(TKW) ke luar negeri yang tidak sesuai dengan apa yang dijanjikan oleh agen. Agen penyalur menjanjikan bahwa calon TKW akan dipekerjakan sebagai asisten rumah tangga atau pelayan restoran dengan upah yang lebih besar dibanding dalam negeri sendiri, namun kenyataannya mereka dipekerjakan sebagai pekerja seks komersial dengan paksaan; bahkan, pada suatu kasus seorang pekerja wanita dijual kepada seorang majikan di Malaysia.

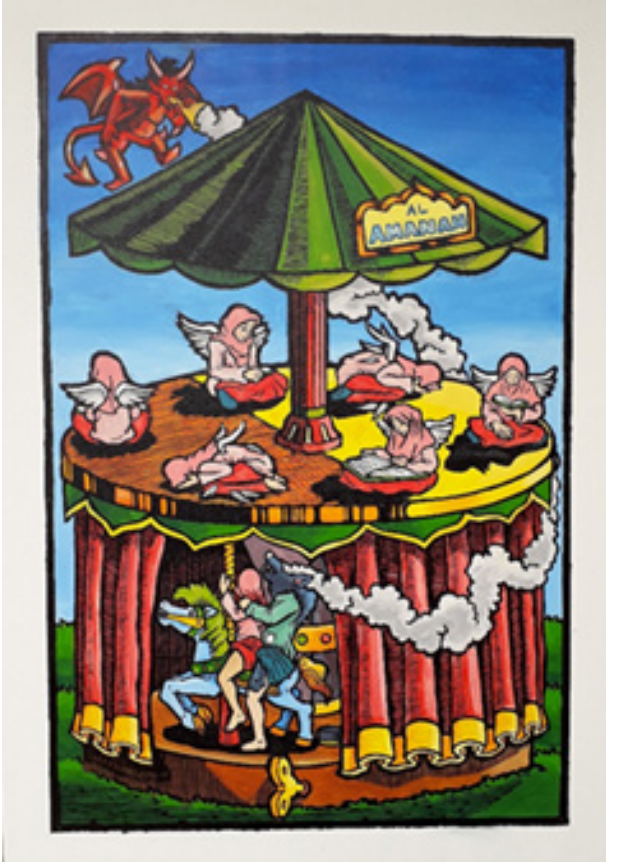

Gb. 2. Prasojo Yulistianto, Skandal Birahi Guru Ngaji, 2020, Monoprint, Woodcut, handcoloring di Kanvas, $100 \times 70 \mathrm{~cm}$

Sumber: (Dokumentasi Penulis)

Pelecehan seksual di tempat kerja berbeda dengan pelecehan seksual lain pada umumnya, karena pelecehan tersebut dilakukan di tempat yang berkaitan langsung dengan pencarian nafkah seseorang. Pelecehan seksual di tempat kerja sering dijadikan sebagai kekuatan kekuasaan dan dapat terjadi di setiap level pekerjaan, dari perekrutan kerja hingga promosi jabatan. Pelecehan seksual di tempat kerja dapat mencakup pendekatan seksual secara langsung maupun tidak, sebagai contoh pekerja yang lebih tinggi jabatannya meminta bawahannya melakukan tindakan seksual dengan dirinya. Pelecehan seksual di tempat kerja juga mencakup mengintimidasi atau tidak mengikutsertakan wanita sehingga dapat membahayakan status pekerjaan wanita itu. Contoh lain adalah dalam dunia penerbangan, di mana sudah menjadi rahasia umum sisi gelap di balik pekerjaan pramugari, beberapa dari mereka diminta untuk melayani pilot maupun seseorang yang memiliki jabatan di maskapai penerbangan demi kelancaran karir pramugari tersebut dan agar jam terbang terus meningkat.

Dari kasus dan fenomenon tersebut, wanita seolah dianggap hanya sebatas makhluk visual semata dan harkat martabatnya lebih rendah dibanding pria, sehingga dipermainkan dan diatur segala pergerakannya dengan cara yang tidak baik. Kebijakan seperti contoh pramugari yang seragamnya didesain agar menunjukkan lekuk tubuh dan bagian rok yang terbelah menunjukkan betis hingga pahanya adalah kebijakan yang seharusnya ditiadakan, caranya adalah dengan desain pakaian yang lebih tertutup. Perihal tuntutan lain di luar pekerjaan di mana pramugari diminta melayani atau berkencan dengan atasannya, tidak semua pramugari menginginkan hal tersebut.

Penulis menggambarkan sosok wanita sebagai objek sasaran seperti dalam permainan di pusat game hiburan (Timezone, Fun Zone,dll). Permainan ini menyenangkan bagi pemukulnya (pemain), namun penderitaan yang diterima oleh objek sasarannya yaitu wanita, di mana saat mereka ingin angkat bicara dan mengungkapkan apa yang dialaminya di dunia kerja kepada orang terdekat atau dunia luar, akan segera diberi ancaman yang menyangkut keselamatan diri atau berkaitan dengan karir si wanita; di sisi lain wanita juga membutuhkan pekerjaan tersebut, sehingga terjadi dilema dalam diri wanita itu. Sosok penguasa (pemain) digambarkan sebagai makhluk setengah serigala untuk menunjukkan sifat kebinatangan dan semakin hilangnya nilai kemanusiaan. Sosok serigala dipilih sebagai metafora karena sifatnya serigala yang kuat bila bersama kawanannya, 
seperti orang-orang yang memiliki jabatan pastilah bersekongkol dengan sesamanya untuk membuat kebijakan-kebijakan yang hanya menguntungkan bagi diri atau kelompok mereka saja, tanpa memedulikan penderitaan pekerja bawahannya, yang dalam kasus ini adalah wanita, sebagai korban pelecehan seksual. Palu yang terbuat dari emas adalah alat sebagai metafora harta, tahta, aturan, di mana semua itu dapat disalahgunakan demi kepentingan pribadi, atau dalam karya penulis, untuk mengancam pribadi korban, dan membeli hukum.

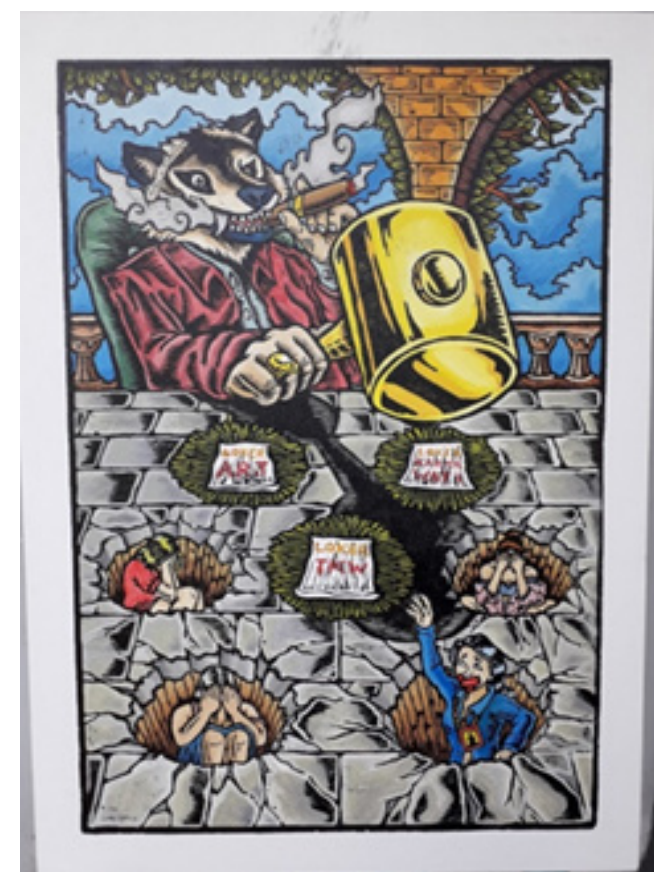

Gb. 1. Prasojo Yulistianto, Represi Dunia Kerja Terhadap Wanita, 2020

Monoprint, Woodcut, handcoloring di Kanvas, $100 \times 70 \mathrm{~cm}$

Sumber: (Dokumentasi Penulis)

Pada karya ini penulis ingin mengkritisi kasus pelecehan seksual yang dilakukan oleh oknum guru ngaji kepada anak didiknya di lembaga pendidikan keagamaan seperti di pondok pesantren maupun di Taman Pendidikan Al-Qur'an (TPA), di mana tempat tersebut seharusnya menjadi tempat yang paling aman untuk anak didik, dan orang tua menitipkan anaknya untuk dibekali akhlak yang mulia. Akan tetapi, beberapa kasus oknum guru ngaji melakukan hal yang jauh dari kata mulia. Ironisnya, tempat yang diberi nama "Amanah" yang artinya dapat dipercaya, tidak sesuai harapan. Guru ngaji yang seharusnya memiliki akhlak yang baik pun tak luput dari bisikan setan. Indah tampak luar belum tentu juga di dalam.

Pada 29 Januari 2020 sebuah media online, suarajatim.id, memberitakan bahwa pimpinan pondok pesantren di Kecamatan Plemahan, Kabupaten Kediri, telah mencabuli santrinya yang masih berusia 12 Tahun atau duduk di kelas $6 \mathrm{SD}$, diakuinya tindakan tersebut dilakukan sejak korban duduk di bangku kelas 3 SD. Kasus ini terbongkar setelah korban menceritakan apa yang dialaminya pada sahabatnya karena sudah tidak kuat menjadi budak nafsu sang guru (https: / /jatim.suara.com/ $\mathrm{read} / 2020 / 01 / 29 / 104024 /$, diakses 20 Februari 2020)

Penulis menggambarkan situasi para santri wanita yang sedang duduk mengaji penuh khidmat, letaknya di ketinggian menggambarkan dunia atas atau hubungan manusia dengan Sang Pencipta, sayap pada punggungnya memiliki narasi bahwa mereka seperti manusia setengah malaikat, berakhlak mulia dan dapat terbang tinggi menuju cita-citanya, serta calon penghuni Surga. Namun diantaranya ada santri yang bulu sayapnya habis tak bersisa, sehingga sulit untuk terbang. Posisi sedang meringkuk penuh kesedihan dan rasa malu yang mendera. Pada tirai yang terbuka sedikit terlihatlah apa yang santri tersebut alami.

Penulis memetaforakan tindak pelecehan oleh oknum guru ngaji kepada santri tersebut dengan aktivitas "bermain kuda-kudaan" di dunia bawah atau dunia hawa nafsu yang berkonotasi negatif. Sedangkan oknum guru ngaji dimetaforakan sebagai siluman serigala yang wajahnya menengadah ke atas menunjukkan sedang meraung dengan kepuasan seksnya. Asap yang terlihat sebagai metafora bisikan setan yang mengendalikan hawa nafsu dan menghilangkan hati nurani. Alat putar yang biasa ditemui pada mainan dan hubungannya dengan tempat tersebut adalah tanda adanya suatu mekanisme 
yang digerakkan oleh sang oknum dalam melancarkan aksinya. Payung berwarna hijau diasosiasikan sebagai suatu tempat berteduh dengan nuansa religius. Secara keseluruhan visual, penulis memunculkan suatu ironi dari harapan dan ekspektasi yang tidak terpenuhi. Suatu tempat yang terlihat aman dan menyenangkan pun kadang memiliki cerita kelamnya.

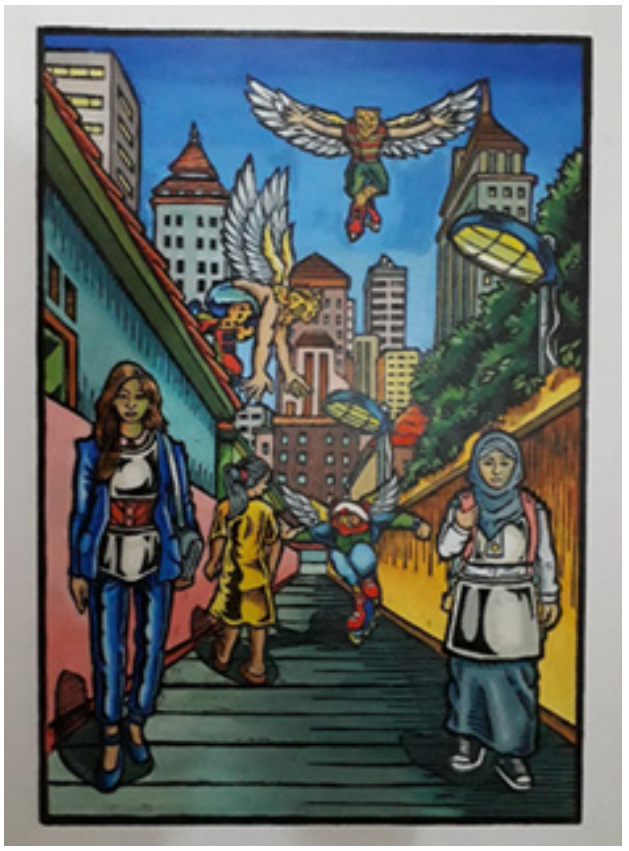

Gb. 3 Prasojo Yulistianto, Mewabah Meraba, 2020, Monoprint, Woodcut, handcoloring di Kanvas, $100 \times 70 \mathrm{~cm}$

Sumber: (Dokumentasi Penulis)

Kasus-kasus begal payudara kian marak terjadi di Indonesia, bermula dari ulah jahil pria berkendara dengan motor yang memegang payudara wanita pejalan kaki, kejadian tersebut tertangkap kamera CCTV yang akhirnya tersebar luas dan membuat orang lain berpikiran untuk melakukan hal yang sama. Tindak kejahatan ini dapat menjadi wabah penyakit pola pikir di masyarakat, berbuat kriminal yang diliputi adrenalin sembari pergi secepatnya menghilangkan jejak tanpa ingin bertanggung jawab. Kejadian ini sering terjadi di gang sempit di area pemukiman warga, pelakunya pun bisa siapa saja termasuk driver ojek online yang sedang melintas, yang mana videonya belum lama tersebar di media sosial. Apabila kasus semacam ini dibiarkan terus menerus, maka akan ada beberapa penyesuaian yang dilakukan oleh para wanita untuk mencegah hal tersebut menimpanya, seperti menggunakan pelindung dada dan pinggul yang terbuat dari besi, mengesampingkan kenyamanan untuk menjaga kehormatan. Pada dasarnya bukan baju wanita yang berhak disalahkan, namun cara berpikir dan bertindak yang dimiliki oleh pria yang diwujudkan ke dalam tindakan tak senonoh tersebut.

Figur perpaduan antara manusia dan hewan (cheetah dan burung) adalah metafora dari pelaku begal payudara yang tidak pernah disangka atau dicurigai oleh calon korbannya; ibarat seperti burung di jalan yang sering tidak dihiraukan oleh manusia, memiliki kaki dan wajah cheetah dengan sepatu roda menggambarkan pelaku begal yang memiliki akses cepat menghilangkan jejak setelah melakukan aksinya. Figur wanita pekerja dan pelajar yang mengenakan baju pelindung besi adalah bentuk kesadaran untuk mengantisipasi terjadinya begal payudara dan bagian sensitif lainnya. Yang menginspirasi penulis dalam membuat metafora tersebut adalah kejadian barubaru ini, di mana masyarakat yang keluar rumah dengan kesadaran pribadi menggunakan masker untuk mencegah terinfeksi virus Covid-19. Wanita yang menjadi korban dalam karya ini adalah wanita yang masih menganggap remeh ancaman begal payudara. Penggunaan warna pada karya ini sebagai penerang dan pembeda objek visual.

\section{E. Kesimpulan}

Kejahatan seksual disebabkan oleh budaya patriarki yang menempatkan pria sebagai warga kelas satu, dominan, superior dan lebih tinggi dari perempuan, sementara wanita menjadi warga kelas dua, inferior dan lebih rendah. Dengan kenyataan tersebut maka akan menimbulkan adanya relasi yang tidak seimbang yakni anggapan masyarakat bahwa pria memiliki kedudukan yang lebih tinggi daripada wanita, sehingga pria merasa lebih berkuasa atas wanita. 
Terlebih lagi praktik sistem kapitalisme turut membuat budaya patriarki tetap ada, dan bahkan menimbulkan kasuskasus kejahatan seksual. Pada sistem kapitalis menghasilkan produk-produk budaya seperti pakaian untuk para wanita remaja yang desainnya terbuka untuk menunjukkan sisi sensual dari pemakainya (contoh celana jin pendek, tanktop, dll).

Pengaruh trend luar negeri turut membentuk selera masyarakat di Indonesia, misalnya pada tahun 1950 gadis remaja dan wanita menggunakan kebaya untuk pakaian sehari-hari, saat ini banyak gadis remaja dengan senang hati memakai baju-baju terbuka tanpa sadar mereka telah menjadi objek visual dari sistem kapitalis. Pada dasarnya membeli pakaian tersebut juga merupakan hak kebebasan masing-masing wanita, namun juga bisa menimbulkan masalah lain, seperti kasuskasus kejahatan seksual yang sering terjadi. Seperti mengingat hukum Newton yang mengatakan ada aksi maka ada reaksi, kaum pria yang menyaksikan aurat wanita bisa tergugah hasrat biologisnya yang merupakan reaksi dari rangsangan indera penglihatannya.

Bagaimanapun, tidak bisa hanya menyalahkan wanita yang berpakaian minim, pria yang tidak bisa mengendalikan hasratbiologisjugamenjadisumbermasalah kasus-kasus pelecehan seksual, terlebih situasi dan kondisinya memungkinkan. Kasus kejahatan seksual juga dapat terjadi secara terstruktur, dalam sistem kapitalis, kaum pemilik modal memiliki kekuasaan yang akhirnya terjun ke arah dominasi atas kaum yang lemah. Industri kebudayaan sudah dikendalikan secara penuh oleh segelintir kaum yang berkuasa, mereka mengendalikan selera pasar, menentukan selera pasar dan golongan konsumen dari harga barang hingga iming-iming image yang mengikuti nilai barang tersebut. Membuat masyarakat menjadi konsumtif dan terdoktrin bahwa faktor ekonomilah yang sangat penting, sehingga kapitalisme itu sendiri menuntut manusia untuk terus bekerja, di sisi lain faktor hasrat biologis para penguasa juga turut mengambil peran dalam mengatur kebijakan yang diberlakukan.

\section{Daftar Pustaka}

\section{Buku \& Jurnal}

Annisa, R. (2007). Kekerasan terhadap Perempuan Berbasis Gender. Rifka Annisa Women's Crisis Center.

Bambang, S. (1996). Postmodernisme: Tantangan Bagi Filsafat. Yogyakarta: Kanisius.

Fakih, M. (1996). Analisis gender \& transformasi sosial. Pustaka Pelajar.

Marianto, M. D. (2015). Art \& Levitation: Seni dalam Cakrawala Quantum. Pohon Cahaya.

Materi Kuliah Online, Walter Benjamin dan Kritik Seni, Oleh Dr. Sugeng Bayu Wahyono, M. Si, pada tanggal 9 April 2020, Pascasarjana Institut Seni Indonesia Yogyakarta.

Raditya, A. (2014). Sosiologi tubuh: membentang teori di ranah aplikasi. Kaukaba.

Ritzer, G., \& Goodman, D. J. (2004). Teori Sosiologi Modern, terj. Alimandan. Jakarta: Kencana.

Ross, C. (2007). Mistik Jepang: Supranatural and Mysterious Japan. Yogyakarta: Pinus Book.

Sp, S. (2006). Trilogi seni: penciptaan, eksistensi, dan kegunaan seni. Badan Penerbit Institut Seni Indonesia Yogyakarta.

Tanama, A. C. (2020). Andre, Cap Jempol Seni cetak Grafis Dari Nol. Yogyakarta: Penerbit SAE.

\section{Sumber Website}

https://jatim.suara.com/ $\mathrm{read} / 2020 / 01 / 29 / 104024 /$ perkosa-santriwati-sejak-kelas-3sd-pimpinan-ponpes-saya-sukaanaknya (diakses pada 20 Februari

2020)

https://www.liputan6.com/global/ read/4010904/kbri-wni-korbankekerasan-seksualpolitikus-malaysia-trauma (diakses pada 4 Mei 2020) 